\title{
Antecedents of trust among buyer and seller within the South African automotive supply chains
}

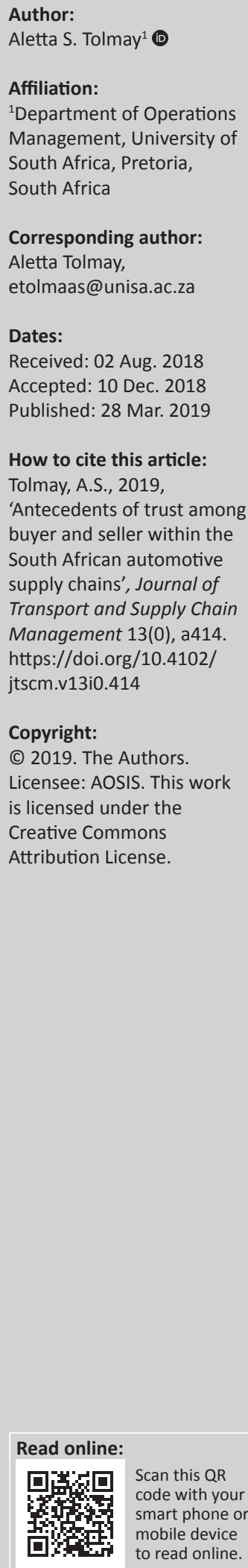

Background: Positive supplier relationships result in trust and eventually sustainability. However, the opposite seems to be true in the South African automotive supply chain relationships that are characterised by conflict. Literature states that in the absence of trust, sustainability is compromised. The problem pertains to the erosion of trust because of conflict between suppliers in the South African automotive supply chains.

Objectives: The main purpose of the research was to address the question: What are the antecedents of trust between buyer and seller within the South African automotive supply chains? The primary objective was to determine the value-adding antecedents of trust followed by presenting the antecedent with the strongest correlation towards trust.

Method: The study was explanatory and descriptive by nature to determine relationships between constructs. The empirical research utilised a quantitative census, thus targeting all senior managers representing Tier 1 automotive component suppliers. A deductive approach through a structured close-ended questionnaire tested the managers' perception on trust. The response rate was $81.4 \%$ with 144 participants. After factor analysis, a path analysis was compiled, depicting the antecedents of trust.

Results: The study found that antecedents showing the strongest correlation with trust were the core offering, inclusive of product delivery and quality followed by personal interaction that forms part of the sourcing process.

Conclusion: The research study makes a theoretical contribution by presenting a conceptual structure on trust by depicting its antecedents. Managerial contributions include recommendations on how to enhance trust through a relational governance strategy.

\section{Introduction}

The sustainability of automotive supply chains in South Africa is important as this industry is substantially contributing 6.9\% towards the country's gross domestic product (AIEC 2018:5). Unfortunately, the automotive supplier relationships within the South African automotive supply chains seem to be strained, and this can result in elevated risk and possible non-sustainability (Naude, Ambe \& Kling 2013:1; Sharma \& Bhat 2014:45).

Supply chain theory emphasises the value of close buyer-seller relationships in the automotive industry (Cheng \& Chen 2016:111). However, global pressures, coupled with suppliers that act opportunistically through late deliveries, poor service, quality defects and limited commitment, eventually culminate in strained relationships (Herko \& Hanna 2017:87; Hiraoka 2013:2; Manzouri, Ab Rahman \& Arshad 2015:85-86; Steinle, Schiele \& Ernst 2014:124). These strained relationships result in a lack of trust between the supplier and the buyer (Steinle et al. 2014:124). Trust between the buyer and the seller is viewed as a vital part of successful automotive supply chain relationships, (Ambe 2014a:51; Wisner, Tan \& Leong 2016:79). Trust has been motivated as vitally important within supply chain relationships (Chao et al. 2013:1060; Özer \& Zheng 2017:3), not least because of the numerous benefits derived from it, which include sustainability (Chou, Techatassanasoontorn \& Hung 2015:4).

In the absence of trust, the supplier might stand a chance of losing the contract with the buyer, thereby sacrificing sustainability (Tolmay 2018:80). Therefore, the benefits that derive from the presence of trust in the buyer-supplier supply chain relationship should not be underestimated (Vieira et al. 2013:265). Unfortunately, Naude et al. (2013:1) state that supplier conflict is hampering the sustainability of South African supply chains. The problem addressed in this article pertains to the erosion of trust because of conflict between suppliers in the South African automotive 
supply chains. This in return threatens to hamper sustainability of the supply chains (Chou et al. 2015:4). Because literature invites more research on trust (Akrout \& Diallo 2017:159), specifically within supply chains (Batsaikhan 2017:3), the research reported on in this article investigated the research question: What are the antecedents of trust between buyer and seller within the South African automotive supply chains? The primary objective of the research was to determine the antecedents of trust, while the secondary objective was to utilise a path analysis to determine the antecedent(s) that have the strongest correlation with trust.

An investigation of 'trust' has become necessary as literature has suggested that trust leads towards sustainability within supply chains (Chou et al. 2015:4). The term 'supply chain sustainability' refers to the triple bottom line that includes the environmental, economic and social dimensions (Silva, Fritz \& Nunes 2017:35). However, Silva et al. (2017:35) have added a fourth dimension to supply chain sustainability, namely governance, which encapsulates a holistic approach towards sustainability and includes strategies to enhance total quality management (TQM), risk management and supplier relationship management. Hence, sustainability, as referred to in this context, encapsulates the continued existence of automotive component suppliers, allowing them to undertake business for the foreseeable future.

Automotive component suppliers have limited parameters for differentiation through price, product quality and logistics (Yeh 2016:137). Therefore, suppliers must utilise the actual supply chain relationship with the buyer to differentiate themselves (Yeh 2016:137) and ensure sustainability through trust (Chao et al. 2013:1060; Özer \& Zheng 2017:3). It is therefore important that automotive suppliers understand the importance of trust in buyer-supplier relationships as well as the governance thereof (Chao et al. 2013:1060; Özer \& Zheng 2017:3).

Although literature has stated the benefits of trust in buyersupplier relationships, more research relating to the conceptualisation of trust within automotive supply chains has been invited (Ashnai et al. 2016:137). This is because of trust being seen as a multifaceted and complex concept (Akrout \& Diallo 2017:159; Eggert, Ulaga \& Schultz 2006:20; Yaqub \& Hussain 2013:436). Furthermore, literature has invited more research on trust in different environments and countries (Vieira et al. 2013:265), such as developing countries (Batsaikhan 2017:3; Niehaus, Feiboth \& Goedhals-Gerber 2018:1), specifically within supply chains (Batsaikhan 2017:3).

Apart from the fact that further investigation has been called for by literature, the research reported on in this article was motivated by the desirable benefits, such as sustainability, that are derived from trust. The article is presented through the lens of social exchange theory (SET) (see Figure 1), and the role of trust within supply chain relationships is discussed, as well as the numerous benefits of trust, including sustainability. Finally, in an aim to better

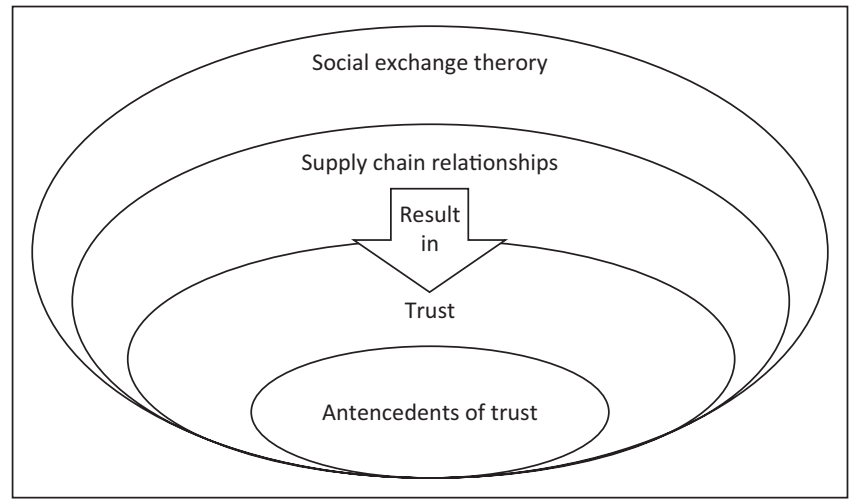

FIGURE 1: Scope of the study.

understand trust, the antecedents of trust are presented through a path analysis depicting the construct showing the strongest correlation (see Figure 1).

Relationships within the supply chains form part of the SET which originated from anthropology (Blau 1964; Cheng \& Chen 2016:111). The SET covers many domains, including behavioural psychology, sociology, philosophy and economics (Chao et al. 2013:1059). Social exchange theory is particularly popular within the supply chain genre to evaluate buyersupplier relationships and strategic alliances (Chao et al. 2013:1059). Vos, Pulles and Schiele (2016:3), for instance, emphasise the importance of positive buyer-supplier relationships and have suggested that trust between buyer and supplier forms the foundation of sustained social exchanges. According to Blau (1964), the relationship under SET will continue or terminate based on the 'exchange' experience between the two partners, be it positive or negative. According to Ashnai et al. (2016:129), trust forms the core of SET. Moreover, SET is explicitly popular within the supply chain genre to evaluate supply chain relationships that result in added value that benefits both parties (Chao et al. 2013:1059; Okdinawati, Simatupang \& Sunitiyoso 2017:85).

\section{Supply chain relationships}

Continuous improvement philosophies, such as TQM and lean principles, promote buyer-supplier relationships in supply chains which promise to achieve a competitive advantage (Slack et al. 2017:485). This is because continuous improvement in supply chains encapsulates not only the improvement of the actual product through the offering of the correct quality, timely delivery, dependability and flexibility but also, very importantly, the improvement of supplier relationships (Slack et al. 2017:485). Thus, contemporary supply chain theory emphasises close relationships between supply chain role players (Cheng \& Chen 2016:111). Positive supplier relationships add value for both parties and result in numerous benefits, including profitability and sustainability (Herko \& Hanna 2017:86).

Owing to increased globalisation pressures, supply chain relationships are often strained, and this has a negative influence on the sustainability of the supply chain in the 
long run (Cheng \& Chen 2016:111; Ghadge et al. 2017:263). These strained relations are unfortunate as they might erode trust, which might result in increased risk for both buyer and seller (Uslaner 2013:62). On the contrary, increased trust may result in a decrease in risk (Uslaner 2013:62). Therefore, Cheng and Chen (2016:111) recommend that supply chain role players foster positive supplier relationships through trust, which in return add value and secure sustainability. With this in mind, Yeh (2016:138) has suggested that it is advisable to invest in a 'relationship governance' strategy where the buyer-supplier relationship is constantly analysed and evaluated in order to determine the value of the buyersupplier relationship. The end result of relationship governance strategies is to create buyer-seller value (Yeh 2016:138). Buyer-seller relationships have the potential to develop into full partnerships (Swink et al. 2011:294-295), known as a strategic alliance (Wisner et al. 2016:119). Through cooperation, buyers and sellers obtain better solutions than those which could have been created individually. The partners then plan together and have full access to knowledge and information, schedules, cost data and designs. These strategic alliance partnerships between buyers and sellers have a central tendency to be 'continuous' with a long-term contract (Bowersox et al. 2012:353). These long-term buyer-seller strategic alliances encourage mutual respect and loyalty, and might result in vertical integration (Swink et al. 2011:295). Therefore, it is evident that within a strategic alliance, both the buyer and the seller will institute active relationship management practices to continue or retain the partnership to realise the potential benefits for both parties.

Literature confirms that supply chain buyer-supplier relationships with elevated value result in trust (Tolmay \& Venter 2017:3; Wisner et al. 2016:79; Yeh 2016:140). If both the buyer and the supplier are willing to mutually trust one another, the continuation of the buyer-seller relationship is secured (Chen \& Lin 2011:31). Therefore, it might be important to determine the value drivers or antecedents of trust.

According to Ulaga and Eggert (2006:128) and Eggert et al. (2006:21), value can be added through three drivers, namely a core offering, the sourcing process and customer operations. These value drivers (Eggert et al. 2006:22) were tested in a diverse market segment by Ulaga and Eggert (2006:13) within the USA. However, the aim of their study was to determine the value driver with the strongest correlation towards 'relationship value' - not trust - which was the aim of the research reported on in this article. Ulaga and Eggert (2006:13) found the strongest value driver to be the sourcing process followed by customer operations and then the core offering. Sun et al. (2014:80) repeated the study of Ulaga and Eggert (2006:13) within the Taiwanese ICT industry and found the strongest driver towards relationship value to be the souring process, followed by the core offering and lastly the customer operations. Tolmay and Venter (2017:6) later tested the same value drivers within the South African automotive supply chains and also found the strongest correlations towards relationship value as the sourcing process, followed by the core offering and lastly the customer operations. The author of this article could not find evidence that this model was tested specifically on trust and not relationship value, as previously tested. The contribution of the research reported on in this article was spurred by this void in literature.

The first value driver, the core offering, comprises delivery performance and product quality. The first aspect, delivery performance, relates to the correct offering which should be provided on time with the required accuracy. The supplier is also required to incorporate flexibility, should schedules and quantities change (Eggert et al. 2006:21). The second aspect, product quality, relates to product reliability and performance, and quality that is consistent and reliable. In the automotive industry supply chain, the core offering is important as automotive supply chains are strongly driven by technical performance measures, such as quality (TQM), logistics (justin-time) and product specifications, with no room for error (Tolmay \& Venter 2017:7).

The second value driver is the sourcing process where the component supplier provides service support through personal interaction with the buyer. The service support encapsulates product-related services, with the supplier providing relevant information and advice on the product as required by the buyer (Eggert et al. 2006:21). This activity is important as automotive supply chains constantly rely on quality improvements in the product offerings. Personal interaction is also significant during the sourcing process as the buyer and the supplier share mutual goals and are in regular communication with each other. In addition to this, the buyer can also assist by providing relevant problemsolving ideas (Eggert et al. 2006:21).

The third value driver is customer operations, including specific expertise, such as market knowledge, as well as development and improvement advice on existing products (Eggert et al. 2006:21). The customer operations function also refers to time-to-market where the supplier assists with design tasks, prototype development and product testing and validation (Eggert et al. 2006:21). The customer operations function is important in automotive supply chains as quicker turnaround times are required.

Various authors (Coenen, Von Felten \& Waldburger 2012:110; Eggert et al. 2006:21; Heinrich, Zellner \& Leist 2011:227; Ulaga \& Eggert 2006:128) seem to agree with these three value drivers and the fact that they lead towards added value, including trust - but no evidence could be found substantiating this statement.

Trust, as the result of strategic buyer-supplier relationships (Wisner et al. 2016:79), is essential for the creation of value and promises to result in sustainability (Herko \& Hanna 2017:86). Gounaris $(2005: 127)$ promises that ' $t$ the more the customer trusts the supplier, the higher the perceived value of relationship'. It is important in buyer-supplier relationships 
that partners trust each other, as 'no real collaboration can exist in supply chain relationships without meaningful trust' (Bowersox et al. 2012:353). The presence of trust can substantially enhance the value of the buyer-seller relationships (Saban \& Luchs 2011:42; Mandal 2015:2).

Heinrich et al. (2011:227) state that the relationship and its associated value directly result in trust. Therefore, it seems as if relationship value drivers are the antecedents of trust.

\section{Trust in supply chain relationships}

The Oxford Dictionary defines trust as the 'firm belief in the reliability, truth, or ability of someone or something' (oxforddictionary.com 2018). More focussed on the business environment, Morgan and Hunt (1994:23) define trust as the '... belief that another company will perform actions that will result in positive outcomes for the firm as well as not take unexpected actions that result in negative outcomes'. Morgan and Hunt (1994:24) state that trust is central to relational exchanges and results in a commitment with a longer relational exchange focus. Trust within automotive supply chains specifically, according to Tolmay (2018:87), is visualised as the assurance of integrity and reliability between the supply chain buyer and seller in the long-term. In the absence of trust, the risk prevails that a contract might be suspended; therefore, it is important to enhance trust through buyer-seller relationships (Vieira et al. 2013:266).

In the presence of trust, a party is perceived as reliable with a high degree of integrity, which is associated with fairness, commitment, honesty, competence, responsibility, helpfulness and benevolence (Morgan \& Hunt 1994:23). Hofstede et al. (2006:122) state that trust within supply chains comprises enforceable and intrinsic trust. The enforceable trust means trust through good performance, whereas intrinsic trust relates to consent vulnerability. Vulnerability captures the constant and basic needs of human beings to associate with other people who are perceived as trustworthy. Enforceable trust seems to be applicable to automotive supply chains when the buyer (or trustor) expands or terminates contracts based on the performance of the supplier. Therefore, the performance of the trustee (supplier) is rewarded or punished accordingly by the trustor (customer or buyer) (Hofstede et al. 2006:124).

Bowersox et al. (2012:353-354) define two types of trust, namely reliability-based trust and character-based trust. Reliability-based trust is based on the ability and willingness of the supply chain partner to perform exactly towards deliverables as promised and expected. Character-based trust is based on the organisation's philosophy and culture. It originates from the principle that parties in the supply chain (buyers and suppliers) have each other's best interest at heart and will consider the impact of all actions against the best interest of the other partner, as 'trusting partners believe that each will protect the other's interest' (Bowersox et al. 2012:354). The author views reliability-based trust as applicable to supplier relationships within the automotive supply chains, as suppliers are expected to do what is right and supply products reliably according to expectations, product specifications and time schedules.

Research specifically undertaken within the automotive supply chains of the United States of America (USA), Japan and Europe found that a trust-centric approach to suppliers, rather than a command-and-control approach, seems to be more advantageous (Saban \& Luchs 2011:52). The command-and-control approach is usually applicable to a transactional collaboration where the supplier is kept at arm's length and is constantly monitored. In this case, the supplier's impact on the buyer-supplier relationship is relatively low. Thus, the buyer can easily dissolve the partnership and find a new supplier in the market. In contrast to this, the trust-centric approach between buyer and supplier enjoys a high degree of strategic collaboration through knowledge sharing and innovation. In addition, both parties are willing to invest in each other by means of effort, energy and time to secure the long-term relational exchange (Saban \& Luchs 2011:52).

Factors that might negatively influence trust include language barriers, geographical distance and differences in the backgrounds of the parties involved (Herko \& Hanna 2017:88; Hofstede et al. 2006:124). Therefore, it is important to test trust within the South African automotive supply chains, as these role players are mostly from different countries of origin (Japan, United States [US] and Germany) and are physically far removed from the buyer.

Trust has numerous benefits, which include financial dimensions (comprising, among many benefits, sustainability and lower transaction costs) and performance dimensions (including, among many, commitment and supplier performance) (see Table 1).

Trust between the buyer and the seller achieves a socially optimal equilibrium, which is beneficial for all parties involved (Batsaikhan 2017:2). In addition to this, transaction cost is lowered (see Table 1) in the presence of trust, and more desirable behaviour (Herko \& Hanna 2017:88) exists between the buyer and the seller, such as increased supplier performance (Vieira et al. 2013:266). At the same time, trust in the supplier might increase innovation, quality and efficiency, as well as problem-solving abilities and the sharing of knowledge and information (see Table 1). Perhaps, the most desired benefit of trust is that it results in commitment and sustainability where the buyer-supplier relationship is sealed in a long-term relational exchange (see Table 1). This supply chain sustainability refers to the holistic approach where environmental, economic, governance and social dimensions are considered (Silva et al. 2017:35).

As more research on the conceptualisation of trust within supply chains has been invited, this article aims to contribute towards literature through the conceptualisation of trust. 
TABLE 1: Benefits of trust.

\begin{tabular}{|c|c|c|}
\hline Dimensions & Benefits of trust & Author \\
\hline \multirow[t]{5}{*}{ Financial } & Increased financial benefits & $\begin{array}{l}\text { Akrout and Diallo (2017:159) } \\
\text { Herko and Hanna (2017:88) }\end{array}$ \\
\hline & Business expansion & Akrout and Diallo (2017:159) \\
\hline & Sustainability & $\begin{array}{l}\text { Badenhorst-Weiss and Tolmay (2016:3) } \\
\text { Cheng and Chen (2016:111) } \\
\text { Ebrahim-Khanjari, Hopp and Iravani } \\
\text { (2012:447) } \\
\text { Ghadge et al. (2017:263) } \\
\text { Tolmay (2018:80) }\end{array}$ \\
\hline & Business retention & $\begin{array}{l}\text { Fang et al. (2014:408); } \\
\text { Saban and Luchs (2011:47) }\end{array}$ \\
\hline & Lower transaction costs & $\begin{array}{l}\text { Herko and Hanna }(2017: 88) \\
\text { Vieira et al. }(2013: 266)\end{array}$ \\
\hline \multirow[t]{8}{*}{ Performance } & Desirable behaviour & Herko and Hanna (2017:88) \\
\hline & Enhanced problem-solving & Batsaikhan (2017:2) \\
\hline & Increased innovation & $\begin{array}{l}\text { Saban and Luchs (2011) } \\
\text { Tolmay (2012); } \\
\text { Vieira et al. (2013) }\end{array}$ \\
\hline & Resulting in business success & $\begin{array}{l}\text { Bloom, Sadun and Reenen (2012) } \\
\text { Batsaikhan }(2017: 2)\end{array}$ \\
\hline & $\begin{array}{l}\text { Increased supplier } \\
\text { performance }\end{array}$ & $\begin{array}{l}\text { Ambe (2014:51) } \\
\text { Beneke et al. (2011:62) } \\
\text { Vieira et al. (2013:266) }\end{array}$ \\
\hline & $\begin{array}{l}\text { Knowledge and information } \\
\text { sharing }\end{array}$ & $\begin{array}{l}\text { Ambe (2014:50) } \\
\text { Vieira et al. (2013:266) }\end{array}$ \\
\hline & $\begin{array}{l}\text { Increased supply chain } \\
\text { performance efficiency and } \\
\text { quality }\end{array}$ & Ambe (2014:51) \\
\hline & Increased commitment & $\begin{array}{l}\text { Ashnai et al. (2016:129) } \\
\text { Čater and Čater (2010:1321) } \\
\text { Kač, Gorenak and Potočan (2015:77) } \\
\text { Li et al. (2012) } \\
\text { Morgan and Hunt (1994:24) } \\
\text { Tolmay (2018:80) } \\
\text { Walter, Mueler and Helfert (2000:1) }\end{array}$ \\
\hline
\end{tabular}

Therefore, value-adding antecedents of trust will be depicted, and secondly, the antecedent(s) with the strongest correlation with trust will be determined.

\section{Research methods}

The buyer-supplier relationship and associated aspects have been analysed in the literature from both the view of the buyer (customer) and the seller (supplier) (Ritter \& Walter 2012:136). However, this article only focusses on the buyers' perspective.

The study on which this article is based formed part of a larger quantitative empirical study. The study was explanatory and descriptive in nature, as it expected to determine relationships between constructs (Saunders, Lewis \& Thornhill 2009:140). A deductive research strategy was followed to better understand a social science phenomenon (Saunders et al. 2009:125), in this case, identifying the most prominent antecedents of trust.

Before starting with the actual research, the researcher ensured that ethical compliance requirements were met in line with the ethics review committee of the applicable tertiary institution. The researcher submitted an application explaining the methodology and ethical compliance to the ethics review committee, and an ethical clearance certificate for the research study was issued.

In preparation for the actual research, the questionnaire was compiled by utilising the survey instrument designed by
Ulaga and Eggert (2006:134) and Eggert et al. (2006:26) which is based on the three value drivers for relationships, namely, core offering, sourcing process and customer operations. A total of 16 items were utilised (see Table 3). The questionnaire utilised a seven-point measurement scale aligned with the seminal study by Morgan and Hunt (1994:35) and Eggert et al. (2006:26), where respondents had to indicate their perceptions - that formed the unit of analysis - using statements ranging from 1 = 'strongly disagree' to 7 = 'strongly agree'. The questionnaire items from Morgan and Hunt (1994:35) (see Table 3) on trust and Eggert et al. (2006:26) (see Table 4) on value drivers were utilised, as presented by the respective studies.

Before distributing the questionnaire, a validation process was first conducted with three South African automotive industry experts. The purpose of this process was to test whether the questions from research previously undertaken in the United States (Morgan \& Hunt 1994) and Germany (Eggert et al. 2006:26), respectively, were applicable to the South African automotive context. The validation process confirmed that the questions were stated clearly and were applicable to the South African automotive supply chains.

The questionnaires were then distributed to managers of all Tier 1 suppliers who are members of the National Association of Allied and Automotive Component Manufacturers (NAACAM). The Tier 1 supplier is the direct supplier to the OEM (original equipment manufacturer) such as Toyota. NAACAM was established in 1980, and 140 members represent the interests of the South African automotive component manufacturers. Almost $70 \%$ of South Africa's first tier (Tier 1) component manufacturers are NAACAM members (AIEC 2015:7). An email invitation containing a link to the Web-based survey hosted by SurveyMonkey was sent to the sampling frame. Non-respondents were contacted telephonically, through a total of three waves over a 60-day period, and encouraged to participate in the research. The survey was directed at senior managers, namely, technical managers, procurement managers and chief executive officers. Of the potential 140 participants to the survey, 114 respondents participated. Hence, a response rate of $81.4 \%$ was achieved. However, not all respondents answered all the questions. The questionnaires received back from the respondents were cleaned and captured using SPSS 24.0. The findings are presented in Table 2 .

According to demographical information obtained, a representative response spread was achieved. The respondents represented companies from all four provinces comprising automotive clusters, different company sizes, according to shareholding, turnover and number of employees per company. The respondents were also requested to indicate their position in the organisation. Of the 98 respondents, 51 (52.0\%) held senior management or CEO positions, while 37 (37.8\%) of them indicated that they were procurement or administrative managers, whilst 10 $(10.2 \%)$ respondents stated that they were technical managers (see Table 2). The data analysis included an exploratory factor analysis (EFA), followed by a path analysis. 
TABLE 2: Respondents profile.

\begin{tabular}{|c|c|c|}
\hline Profile & $N$ & $\%$ \\
\hline \multicolumn{3}{|l|}{ Shareholding } \\
\hline Local shareholding & 31 & 29.2 \\
\hline $\begin{array}{l}\text { International } \\
\text { shareholding }\end{array}$ & 47 & 44.3 \\
\hline $\begin{array}{l}\text { Mixture - local and } \\
\text { international shareholding }\end{array}$ & 28 & 26.4 \\
\hline Total & 106 & - \\
\hline \multicolumn{3}{|l|}{ Company turnover } \\
\hline ROM-R5M & 5 & 5.0 \\
\hline$>$ R5M-R50M & 17 & 16.8 \\
\hline$>$ R50M-R200M & 25 & 24.7 \\
\hline$>\mathrm{R} 200 \mathrm{M}$ & 54 & 53.5 \\
\hline Total & 101 & - \\
\hline \multicolumn{3}{|l|}{ Employees } \\
\hline 1-20 employees & 2 & 1.9 \\
\hline 21-50 employees & 10 & 9.3 \\
\hline 51-200 employees & 40 & 37.4 \\
\hline > 200 employees & 55 & 51.4 \\
\hline Total & 107 & - \\
\hline \multicolumn{3}{|l|}{ Province } \\
\hline Gauteng & 49 & 46.7 \\
\hline KZN & 10 & 9.5 \\
\hline Eastern Cape & 34 & 32.4 \\
\hline Western Cape & 12 & 11.4 \\
\hline Total & 105 & - \\
\hline \multicolumn{3}{|l|}{ Position } \\
\hline CEO/Senior manager & 51 & 52.0 \\
\hline Technical manager & 10 & 10.2 \\
\hline $\begin{array}{l}\text { Administrative/ } \\
\text { procurement manager }\end{array}$ & 37 & 37.8 \\
\hline Total & 98 & - \\
\hline
\end{tabular}

M, million; KZN, KwaZulu-Natal; CEO, chief executive officer; $R$, rand.

\section{Results}

The research question under investigation was: What are the antecedents of trust between buyer and seller within the South African automotive supply chains? Therefore, trust (dependent variable) was established by utilising a three-item scale (see Table 3) obtained from the seminal research by Morgan and Hunt (1994). The focus of the study was on antecedents of trust, while trust, as depicted by Morgan and Hunt (1994), comprised one factor made up of three items (which is considered the minimum number of items in a scale and thus solid) (Castello \& Osborne 2005:3; Henson \& Roberts 2006:408).

The items relating to trust were (Table 3):

- In our relationship, Supplier A demonstrates a high level of integrity (Cronbach's alpha $=0.906$ ).

- In our relationship with Supplier A, our firm feels that Supplier A can be trusted (Cronbach's alpha $=0.938$ ).

- In our relationship, my firm feels that Supplier A can be counted on to do what is right (Cronbach's alpha $=0.935)$.

A high Cronbach's alpha coefficient (0.917) was reported for the trust scale (see Table 3). This exceeds the generally agreed-upon lower limit of 0.70 for the Cronbach's alpha coefficient for internal consistency, as recommended by Pallant (2011:303). It was confirmed that the respondents were in agreement with the importance of trust.
TABLE 3: Construct scales for trust.

\begin{tabular}{|c|c|c|c|c|c|c|}
\hline $\begin{array}{l}\text { Dependent } \\
\text { variable }\end{array}$ & Questions & $\begin{array}{l}\text { Factor } \\
\text { loadings }\end{array}$ & $\begin{array}{l}\text { Cronbach's } \\
\text { alpha for } \\
\text { construct }\end{array}$ & $\begin{array}{l}\text { Mean of } \\
\text { individual } \\
\text { items }\end{array}$ & $\begin{array}{l}\text { Factor } \\
\text { mean }\end{array}$ & $\begin{array}{l}\text { Std. dev. } \\
\text { for factor }\end{array}$ \\
\hline \multirow[t]{3}{*}{ Trust } & $\begin{array}{l}\text { In our } \\
\text { relationship, } \\
\text { my firm feels } \\
\text { that Supplier } \\
\text { A can be } \\
\text { counted on to } \\
\text { do what is } \\
\text { right. }\end{array}$ & 0.906 & 0.917 & 5.786 & 5.866 & 0.929 \\
\hline & $\begin{array}{l}\text { In our } \\
\text { relationship } \\
\text { with Supplier } \\
\text { A, our firm } \\
\text { feels that } \\
\text { Supplier A can } \\
\text { be trusted. }\end{array}$ & 0.938 & - & 5.939 & - & - \\
\hline & $\begin{array}{l}\text { In our } \\
\text { relationship, } \\
\text { Supplier A } \\
\text { demonstrates } \\
\text { a high level of } \\
\text { integrity. }\end{array}$ & 0.935 & - & 5.800 & - & - \\
\hline
\end{tabular}

Source: Morgan, R.M. \& Hunt, S.D., 1994, 'The commitment-trust theory of relationship marketing', The Journal of Marketing 58(3), 20-38. https://doi.org/10.1177/0022242 99405800302

Std. dev., standard deviation.

To assess the measurement model for the independent factors, as a first step, an EFA was conducted on the 16 items. The aim of this analysis was to identify the hypothetical construct factors emerging from the data and if these related to the original theorised factors and conceptual model. An orthogonal rotation method was utilised as the analytical procedure for the study, as it provides a separation of factors (Pallant 2011:185).

Inspection of the correlation matrix (see Table 5) produced from the EFA revealed that all the coefficients were higher than 0.5, motivating the suitability of the factor analysis (Pallant 2011:199). The Kaiser-Meyer-Olkin value was 0.898 , which exceeded the recommended minimum value of 0.6 (Kaiser 1970,1974), and the Bartletts' test of Sphericity (Bartlett 1954) was statistically significant $(p<0.01)$, which further supported the factorability of the correlation matrix.

From the EFA, four factors were identified explaining a cumulative $72 \%$ of the variance in the overall scale response. Each of the items also showed strong loadings onto the identified factors (see Table 4). All items were therefore retained. The four factors were labelled as follows: product delivery and quality (F1), personal interaction (F2), product development support (F3) and improving time-to-market (F4) (see Table 4). The core offering, namely, product delivery and quality (F1), as well as the sourcing process with personal interaction (F2) corresponded with the factors of the study undertaken by Eggert et al. (2006). However, the customer operations function revealed two sub-factors rather than a single factor, namely, product development support (F3) and improving time-to-market (F4) (see Table 4).

A second phase of the model assessment involved conducting a confirmatory factor analysis (CFA). This phase more critically assesses the measurement model as it emerged from the EFA. The CFA model was found to be an acceptable 


\begin{tabular}{|c|c|c|c|c|c|c|}
\hline Constructs and questions & Factor loadings & $\begin{array}{l}\text { Cronbach's alpha } \\
\text { for construct }\end{array}$ & $\begin{array}{c}\text { Mean of } \\
\text { individual items }\end{array}$ & $\begin{array}{l}\text { Std. dev. for } \\
\text { individual items }\end{array}$ & Factor mean & Std. dev. for factor \\
\hline \multicolumn{7}{|l|}{ F1 - Product delivery and quality (Core offering) } \\
\hline $\begin{array}{l}\text { Supplier A has the ability to secure product quality } \\
\text { consistency. }\end{array}$ & 0.780 & - & 5.798 & 1.122 & - & - \\
\hline $\begin{array}{l}\text { Supplier A provides acceptable delivery accuracy (no } \\
\text { missing or wrong parts). }\end{array}$ & 0.780 & - & 5.737 & 1.153 & - & - \\
\hline Supplier A offers product reliability. & 0.753 & - & 5.904 & 0.892 & - & - \\
\hline $\begin{array}{l}\text { Supplier A makes minimal delivery errors (late, wrong } \\
\text { address, wrong products). }\end{array}$ & 0.737 & - & 5.561 & 1.255 & - & - \\
\hline Supplier A has the ability to meet delivery dates. & 0.654 & - & 5.849 & 1.030 & - & - \\
\hline Supplier A has minimal product rejects (faulty). & 0.607 & - & 5.868 & 1.035 & - & - \\
\hline Supplier A has the ability to address problems. & 0.590 & 0.930 & 5.832 & 1.017 & 5.791 & 0.98834 \\
\hline \multicolumn{7}{|l|}{ F2 - Personal interaction (Sourcing process) } \\
\hline $\begin{array}{l}\text { Supplier A has the ability to provide us with } \\
\text { appropriate information. }\end{array}$ & 0.745 & - & 5.842 & 1.001 & - & - \\
\hline $\begin{array}{l}\text { Supplier A has the ability to give us a feeling of being } \\
\text { treated as an important client. }\end{array}$ & 0.740 & - & 5.728 & 1.131 & - & - \\
\hline Supplier A offers a good working relationship. & 0.703 & - & 5.779 & 1.041 & - & - \\
\hline Supplier A has the ability to provide general know-how. & 0.588 & 0.904 & 5.434 & 1.217 & 5.6974 & 0.96823 \\
\hline \multicolumn{7}{|l|}{ F3 - Product development support (Customer operations) } \\
\hline $\begin{array}{l}\text { Supplier } \mathrm{A} \text { has the ability to assist with new product } \\
\text { development. }\end{array}$ & 0.871 & - & 5.446 & 1.446 & - & - \\
\hline $\begin{array}{l}\text { Supplier A has the ability to help us speed up product } \\
\text { development. }\end{array}$ & 0.715 & - & 5.257 & 1.357 & - & - \\
\hline $\begin{array}{l}\text { Supplier A has the ability to drive innovation in } \\
\text { products. }\end{array}$ & 0.606 & 0.888 & 5.173 & 1.433 & 5.2857 & 1.26859 \\
\hline \multicolumn{7}{|l|}{ F4 - Improving time-to-market (Customer operations) } \\
\hline $\begin{array}{l}\text { Supplier A has the ability to help us improve the cycle } \\
\text { time of all activities in the manufacturing process. }\end{array}$ & 0.758 & - & 4.982 & 1.395 & - & - \\
\hline $\begin{array}{l}\text { Supplier A has the ability to improve our time-to- } \\
\text { market. }\end{array}$ & 0.722 & 0.803 & 5.088 & 1.373 & 5.0442 & 0.27047 \\
\hline
\end{tabular}

Source: Eggert, A., Ulaga, W. \& Schultz, F., 2006, 'Value creation in the relationship life cycle: A quasi-longitudinal analysis', Industrial Marketing Management 35(2006), 20-27. https://doi. org/10.1016/j.indmarman.2005.07.003.

Std. Dev., standard deviation.

fit supported by the following statistics: normed fit index $(\mathrm{NFI})=0.836$ (Byrne 1994), Tucker Lewis index $(\mathrm{TLI})=0.847$ (Hu \& Bentler 1999), comparative fit index (CFI) $=0.889$ (Bollen 1989), root mean square error of approximation $($ RMSEA $)=0.117$ (Fan, Thompson \& Wang 1999), PCLOSE (PCLOSE gives a test of close fit, while $\mathrm{p}$ gives a test for exact fit) $=0.000$ and $\mathrm{CMIN} / \mathrm{DF}$ (DMIN/DF is the minimum discrepancy divided by the degrees of freedom) $=2.605$ (> 0.05) (Pallant 2011:176). Despite marginal fit indices, the factor loadings were higher than 0.8 on average (see Table 4 ).

Next, the Cronbach's alpha coefficients were calculated to further assess the reliability of internal consistency of factors. Alpha values of above 0.8 were reported exceeding the minimum requirement level of 0.7 (Pallant 2011:6). The mean for each of the factors was henceforth calculated based on the summated average of all underlying items. This mean score for each factor served as the proxy measures of the factors and was utilised as the observed variables in the path analysis.

The first factor, product delivery and quality (F1) (core offering) relates to the suppliers' technical performance that includes reliability, product quality and delivery performance. Not surprisingly, F1 was the most highly rated factor (mean of $5.791, \mathrm{SD}=0.988$ ), as this is after all the prime reason why suppliers are appointed in the industry (see Table 4).
Secondly, personal interaction (F2) (sourcing process) (mean of 5.697, $\mathrm{SD}=0.968$ ) relays the personal relationship that the automotive supplier has with the buyer, and it includes aspects such as the sharing of information and how well the client (or buyer) is treated (see Table 4).

Thirdly, product development support (F3) (customer operations) (mean of 5.285, SD = 1.269) comprises the extent to which the supplier assists the buyer with the development of their products.

Fourthly and finally, improving time-to-market (F4) (customer operations) (mean of 5.044, $\mathrm{SD}=1.270$ ) relates to the extent to which the supplier assists the buyer with the speed of introducing products into the market (see Table 4). The respondents, in general, seemed to have less agreement with the last two factors (F3, F4). The standard deviation for the four factors revealed similar variations across the means.

The preliminary analysis furthermore revealed no serious violations of the assumptions of normality, homoscedasticity and linearity. The correlation coefficients calculated between factor scores (F1, F2, F3, F4) (see Table 5) were all lower than 0.9 and did not suggest a concern of multicollinearity (Pallant 2011:151).

Thereafter, a path analysis was conducted through AMOS version 24 software to determine the strength of the four 
TABLE 5: Pearson's correlation.

\begin{tabular}{lccc}
\hline Variable & $\begin{array}{c}\text { F1_Product quality } \\
\text { and delivery }\end{array}$ & $\begin{array}{c}\text { F2_Personal } \\
\text { interaction }\end{array}$ & $\begin{array}{c}\text { F3_Product } \\
\text { development support }\end{array}$ \\
\hline $\begin{array}{l}\text { F2-Personal } \\
\text { interaction }\end{array}$ & $0.710^{*}$ & - & - \\
$\begin{array}{l}\text { F3-Product } \\
\text { development } \\
\text { support }\end{array}$ & $0.629^{*}$ & $0.649^{*}$ & - \\
$\begin{array}{l}\text { F4-Improve } \\
\text { time-to-market }\end{array}$ & $0.537^{*}$ & $0.580^{*}$ & $0.557^{*}$ \\
\hline
\end{tabular}

*, All correlations were significant at a 0.01 level (2-tailed).

factors (independent variables) as predictor variables, and their relationship in explaining the variation in trust (dependent variable). It was found that all correlations measured above 0.5 , and are therefore considered strong (Pallant 2011:134). While these results provide insight into the strength of the underlying bivariate relationships, the aim of the study was to identify those variables that contribute to explaining the variation in trust from a multivariate perspective.

The results of the path analysis, with the applicable standardised regression coefficients ( $\beta$ coefficients), are depicted in Figure 2 as:

- The first factor (F1), product quality and delivery, and the second factor (F2), personal interaction, have the strongest direct effects on trust ( $\beta=0.56$ for F1 and $\beta=0.44$ for F2, $p<0.01)$.

- However, the third factor (F3), product development support, and the fourth factor (F4), improving time-tomarket, do not appear to significantly influence trust directly, $(\beta=-0.01$ for F3 and $\beta=0.06$ for F4, $p<0.01$ ).

- The $R^{2}$ measure indicates that $80 \%$ of the variance in trust can be explained by the model (see Figure 2).

The relationships between the independent variables on the left of the path analysis (F1, F2, F3, F4) (see Figure 2) revealed acceptable discriminant validity $(r<0.90)$ (Pallant 2011:151), and this is indicative of sufficient independence between the factors.

The implications of the above findings are discussed in the following section.

\section{Discussion}

Globalisation brought about various challenges for South African automotive component suppliers. One of the challenges is strained supplier relationships that diminish trust, which in turn threatens sustainability. The problem addressed in this article pertains to the erosion of trust because of conflict between buyers and suppliers in the South African automotive supply chains. As literature has suggested that trust can add value and enhance sustainability, the aim of this study was to answer the research question: What are the antecedents of trust between buyer and seller within the South African automotive supply chains?

The primary objective of the research was to determine the antecedents of trust. To accomplish this, literature was reviewed, and it was found that supply chain theory stresses the value of close buyer-seller relationships in automotive supply chains (Cheng \& Chen 2016:111). According to Ulaga and Eggert (2006:128) and Eggert et al. (2006:21), value can be added through three drivers, namely, a core offering, the sourcing process and customer operations. Literature further states that supply chain buyer-supplier relationships with elevated value result in trust (Tolmay \& Venter 2017:3; Wisner et al. 2016:79; Yeh 2016:140). The research reported on in this article utilised the three value drivers (core offering, the sourcing process and customer operations) and tested their relationship with trust as possible antecedents (Eggert et al. 2006:21).

The secondary objective was to determine the antecedent(s) showing the strongest relationship with trust within the South African automotive supply chains, through a path analysis. After processing the data from the survey, it was found that the respondents were in agreement with the importance of trust within the automotive supply chains. Heinrich et al. (2011:227) state that theoretically the value drivers identified by Eggert et al. (2006) will result in trust, but the author of this article could not find evidence that this model was tested specifically on trust. Thus, the research reported on in this article tested the relationship of four value-adding antecedents (Eggert et al. 2006) with trust. These include product quality and delivery (F1) as part of the core offering, personal interaction (F2) as part of the sourcing process, product development support (F3) and improving time-to-market (F4). The latter two antecedents both represent customer operations.

It was found that product quality and delivery $(\mathrm{F} 1)(\beta=0.56$, $p<0.01)$, as part of the core offering, revealed the strongest coefficient with trust, followed by personal interaction (F2) ( $\beta=0.44, p<0.01)$, which forms part of the sourcing process (see Figure 2).

As product quality and delivery (F1) (as part of the core offering) revealed the strongest coefficient (or positive relationship) with trust, it is implied that the biggest enhancer of buyer-supplier trust is the timely delivery of products by the supplier to the buyer, according to the correct specifications and quality (see Table 4).

When Ulaga and Eggert (2006:13), Sun et al. (2014:80) and Tolmay and Venter (2017:6) tested the coefficient (or positive relationship) of the three value drivers (Eggert et al. 2006) on relationship value (and not trust), they found contradicting outcomes as the sourcing process revealed a higher coefficient with relationship value. All three studies revealed that the sourcing process seems to add the most value to relationship value, whereas the research reported on in this article found that the core offering (product quality and delivery) seems to be the largest contributor towards trust.

This might be the phenomenon because in a qualityconscious environment, such as the automotive supply 


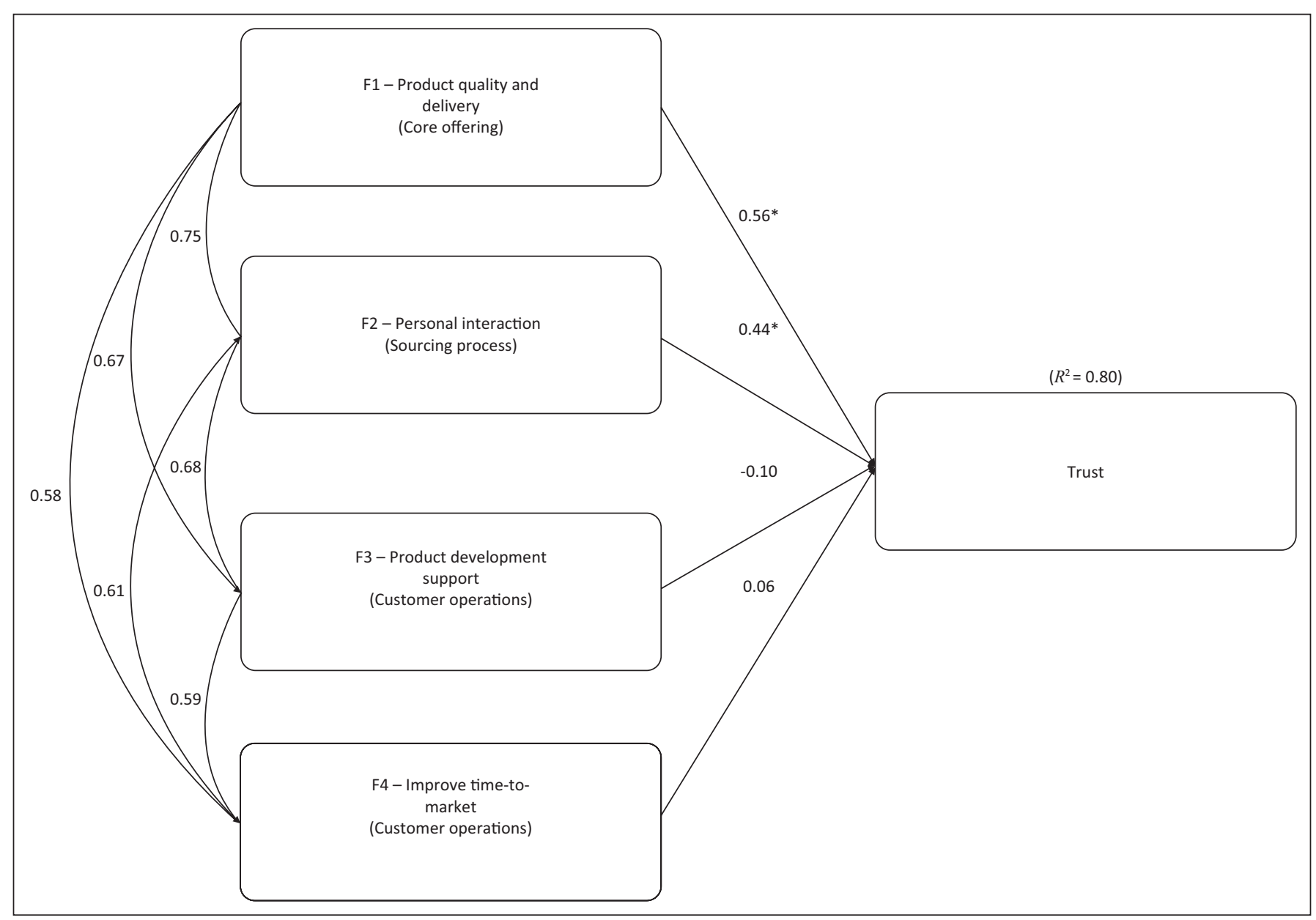

*, Significance $p<0.01$.

FIGURE 2: Results of the path analysis. Standardised coefficients are presented.

chain, there is no room for defects, as they result in financial implications, which negatively influence the buyer and the seller. Failing to comply with product quality and delivery might result in the decrease of trust within the buyersupplier relationship. Suppliers are advised to guarantee that product quality and delivery are consistent, and according to the requirements of the buyer in order to secure trust.

The second most important antecedent that enhances trust seems to be personal interaction (F2) ( $\beta=0.44$, $p<0.01$ ) (as part of the sourcing process), which entails the knowledge of the supplier and also the ability to provide the buyer with appropriate information when required. Ambe (2014:50) and Vieira et al. (2013:266) also confirm the importance of knowledge and information sharing within automotive supply chains. F2 also encapsulates good working relationships with the buyer, and includes treating the buyer as being important (see Table 4). It suggests that if the personal interaction between the buyer and the seller is not enhanced, trust in the relationship will be hampered, which will result in negative consequences. Suppliers are encouraged to prioritise personal interaction activities as part of the buyer-supplier relationship in order to elevate trust.
The two factors that form part of customer operations, namely, support for product development (F3) and improving time-to-market (F4) did not reveal a significant correlation coefficient with trust. Both these factors represent research and development, and it can be argued that this function is usually undertaken by the core Tier 1 company (in the mother country), and is therefore not required by Tier 2 suppliers situated in South Africa. Therefore, these two factors do not seem to affect trust between the buyer and the seller.

\section{Conclusion}

Literature invites more research on the antecedents of trust, and this article makes valuable theoretical and managerial contributions. The theoretical contribution presents a better conceptualisation of trust, by depicting antecedents of trust specifically in automotive supply chains. In an industry characterised by strict quality requirements, it seems that product quality and delivery is the construct that contributed the most towards trust (F1) (as part of the core offering). Therefore, theoretically, buyer-supplier trust is enhanced when the supplier delivers products to the buyer on time, according to the correct specifications and quality.

The managerial implications include inviting managers to focus on product quality and delivery, as well as personal 
interaction, to enhance trust and ultimately to add value within supply chains. In line with theory promoted by Yeh (2016:138), automotive component suppliers might consider introducing a relationship governance strategy where trust, specifically, is incubated through product quality and delivery (core offering) and personal interaction activities (sourcing process). A relationship governance strategy focusses on how value can be added through the relational exchange with the client or the buyer. It is important that managers define the strategic objectives for the relational governance approach on how specifically to add value, that results in trust through product quality and delivery as well as personal interaction.

The failure to enhance trust through supplier relationships might result in increased risk, such as negative financial implications, which might hamper the sustainability of suppliers. As part of the relational governance strategy, a trust-centric approach is advised where both parties collaborate through the sharing of knowledge and innovation, and where both parties are willing to invest in each other by means of the sharing of expertise (know-how), while investing in the relationship and problem-solving.

The study invites more research, especially relating to the supply chains of various industries in different countries. Further research on the expansion of the conceptualisation of supplier relationships, trust and other relational sustainability enablers is invited. As a limitation, the research only approached Tier 1 companies (buyers) who are members of NAACAM, and the results cannot necessarily be generalised to all buyers in the South African or global automotive supply chains. In addition, the research reported on in this article only tested the one-way perception of buyers (Tier 1) regarding suppliers (Tier 2), and not that of suppliers regarding buyers. Future research into two-way perceptions might provide interesting results, such as perception asymmetry, and might deliver additional insightful findings.

\section{Acknowledgements}

The author thanks the statistician, Dr Dion van Zyl, who assisted with additional statistical data analysis and interpretation.

\section{Competing interests}

The author declares that she has no financial or personal relationships that may have inappropriately influenced her in writing this article.

\section{References} AIEC, 2015, Automotive export manual, Zest (Pty) Ltd., Pretoria, ISBN: 978-0-620-
$65335-0$.

AIEC, 2018, Automotive export manual, Zest (Pty) Ltd., Pretoria, ISBN: 978-0-62079400-8.

Akrout, H. \& Diallo, M.F., 2017, 'Fundamental transformations of trust and its drivers: A multi-stage approach of business-to-business relationships', Industrial Marketing Management 66, 159-171. https://doi.org/10.1016/j.indmarman. 2017.08.003
Ambe, I.M., 2014a, 'Determining supply chain practices of vehicle manufacturers in South Africa', Journal of Contemporary Management 11, 47-61.

Ambe, I.M., 2014b, 'Difficulty to overcome supply chain challenges faced by vehicle manufacturers in South Africa'. Journal of Applied Business Research 30(5), 15391550. https://doi.org/10.19030/jabr.v30i5.8806

Ashnai, B., Henneberg, S.C., Naudé, P. \& Francescucci, A., 2016, 'Inter-personal and inter-organizational trust in business relationships: An attitude-behavioroutcome model', Industrial Marketing Management 52, 128-139. https://doi.org/ 10.1016/j.indmarman.2015.05.020

Badenhorst-Weiss, J.A. \& Tolmay, A.S., 2016, 'Relationship value, trust and supplier retention in South African automotive supply chains', Journal of Applied Business Research (JABR) 32(5), 1329-1340. https://doi.org/10.19030/jabr.v32i5.9762

Bartlett, M.S., 1954, 'A note on the multiplying factors for various chi square approximations', Journal of the Royal Statistical Society 16 (Series B), 296-298.

Batsaikhan, M., 2017, 'Trust, trustworthiness, and business success: Lab and field findings from entrepreneurs', Economic Inquiry 55(1), 368-382. https://doi. org/10.1111/ecin.12359

Beneke, J., Adams, E., Demetriou, O. \& Solomons, R., 2011, 'An exploratory study of the relationship between store image, trust, satisfaction and loyalty in a franchise setting', Southern African Business Review 15(2), 59-74.

Blau, P., 1964, 'Justice in social exchange', Sociology Inquiry 34, 193-206. https://doi. org/10.1111/j.1475-682X.1964.tb00583.x

Bloom, N., Sadun, F. \& Reenen, J.V., 2012, 'Organization of firms across countries', The Quarterly Journal of Economics 127, 1663-1705. https://doi.org/10.1093/qje/ qje029

Bollen, K.A. 1989, Structural equations with latent variables, Wiley, New York.

Bowersox, D.J., Closs, D.J., Cooper, M.B. \& Bowersox, J.C., 2012, Supply chain logistics management, 4th edn., McGraw-Hill, New York.

Byrne, B.M., 1994, Structural equation modeling with EQS and EQS/Windows, Sage, Thousand Oaks, CA.

Castello, A.B. \& Osborne, J.W., 2005, 'Best practices in exploratory factor analysis: Four recommendations for getting the most from your analysis', Practical Assessment, Research \& Evaluation 10(7), 1-9.

Čater, T. \& Čater, B., 2010, 'Product and relationship quality influence on customer commitment and loyalty in B2B manufacturing relationships', Industrial Marketing Management 39(8), 1321-1333. https://doi.org/10.1016/j.indmarman.2010.02.006

Chao, C.M., Yu, C.T., Cheng, B.W. \& Chuang, P.C., 2013, 'Trust and commitment in relationships among medical equipment suppliers: Transaction cost and social exchange theories', Social Behavior and Personality: An International Journal 41(7), 1057-1069. https://doi.org/10.2224/sbp.2013.41.7.1057

Chen, T.Y. \& Lin, F.J., 2011, 'Using relationship norms to create appropriate relationship value: Evidence from the credit card industry', Journal of Relationship Marketing 10(1), 28-42. https://doi.org/10.1080/15332667.2011.549006

Cheng, J.H. \& Chen, M.C., 2016, 'Influence of institutional and moral orientations on relational risk management in supply chains', Journal of Purchasing and Supply Management 22(2), 110-119. https://doi.org/10.1016/j.pursup.2016.01.002

Chou, S.W., Techatassanasoontorn, A.A. \& Hung, I.H., 2015, 'Understanding commitment in business process outsourcing relationships', Information \& Management 52(1), 30-43. https://doi.org/10.1016/j.im.2014.10.003

Coenen, C., Von Felten, D. \& Waldburger, D., 2012, 'Beyond financial performance: Capturing relationship value in FM', in P.A. Jensen, T.v.d. Voordt \& C. Coenen (eds.), The added value of facilities management: Concepts, findings and perspectives, pp. 105-122, Polyteknisk Forlag, Copenhagen.

Ebrahim-Khanjari, N., Hopp, W. \& Iravani, S.M.R., 2012, 'Trust and information sharing in supply chains', Production and Operations Management Society 21(3), 444-464. https://doi.org/10.1111/j.1937-5956.2011.01284.x

Eggert, A., Ulaga, W. \& Schultz, F., 2006, 'Value creation in the relationship life cycle: A quasi-longitudinal analysis', Industrial Marketing Management 35(2006), 20-27. https://doi.org/10.1016/j.indmarman.2005.07.003

Fan, X., Thompson, B. \& Wang, L., 1999, 'Effects of sample size, estimation method, and model specification on structural equation modeling fit indexes', Structural Equation Modeling 6, 56-83. https://doi.org/10.1080/10705519909540119

Fang, Y., Qureshi, I., Sun, H., McCole, P., Ramsey, E. \& Lim, K.H., 2014, 'Trust satisfaction, and online repurchase intention: The moderating role of perceived effectiveness of e-commerce institutional mechanisms', MIS Quarterly 38(2), 407-427. https://doi.org/10.25300/MISQ/2014/38.2.04

Ghadge, A., Dani, S., Ojha, R. \& Caldwell, N., 2017, 'Using risk sharing contracts for supply chain risk mitigation: A buyer-supplier power and dependence perspective' Computers and Industrial Engineering 103, 262-270. https://doi.org/10.1016/j. cie.2016.11.034

Gounaris, S., 2005, 'Trust and commitment influences on customer retention: Insights from business to business services', Journal of Business Research 58(2005), 126140. https://doi.org/10.1016/S0148-2963(03)00122-X

Heinrich, B., Zellner, G. \& Leist, S., 2011, Service integrators in business networks The importance of relationship values', Electronic Markets 21(4), 215-235. https://doi.org/10.1007/s12525-011-0075-x

Henson, R.K. \& Roberts, J.K., 2006, 'Use of exploratory factor analysis in published research: Common errors and some comment on improved practice', Educational and Psychological Measurement 66(3), 393-416. https://doi.org/10.1177/0013 164405282485

Herko, R.T. \& Hanna, T., 2017, 'Trust, relationships, and project outcomes: The impact of trust on the success of construction projects', The Journal of Business Inquiry 17(2), 86-96. 
Hiraoka, L.S., 2013, 'Reconfiguring supply chains for a global automotive industry', in J. Wang (ed.), Management innovations for intelligent supply chains, pp. 276-293, J. Wang (ed.), Management innovations for intelligent
Business Science Reference (IGI Global), Hershey, PA.

Hofstede, G., Jonker, C., Meijer, S. \& Verwaart, T., 2006, 'Modelling trade and trust across cultures', in G. Goos, J. Hartmanis \& J. Leeuwen (eds.), 4th International conference, iTrust Management, Pisa, Italy, 16-19 May 2006, pp. 120-134.

$\mathrm{Hu}$, L.T. \& Bentler, P.M., 1995, 'Evaluating model fit', in R.H. Hoyle (ed.), Structural equation modeling: Concepts, issues, and applications, pp. 76-99, Sage, Thousand Oaks, CA.

Kač, M.S., Gorenak, I. \& Potočan, V., 2015, 'Influence of relationship commitment and trust on collaborative behaviour in supply chains', PROMET-Traffic \& Transportation 27(1), 77-84. https://doi.org/10.7307/ptt.v27i1.1575

Kaiser, H.F., 1970, 'A second-generation little Jiffy', Psychometrica 35(4), 401-415 https://doi.org/10.1007/BF02291817

Kaiser, H.F., 1974, 'An index of factorial simplicity', Psychometrica 39, 31-36. https:// doi.org/10.1007/BF02291575

Li, L., Ford, J.B., Zhai, X. \& Xu, L., 2012, 'Relational benefits and manufacture satisfaction: An empirical study of logistics service in supply chain', International Journal of Production Research 50(19), 5445-5459. https://doi.org/10.1080/0020 7543.2011.636388

Mandal, S., 2015, 'Towards an empirical-relational model for supply chain innovation', International Journal of Information Systems and Supply Chain Management (IIISSCM) 8(4), 14-29. https://doi.org/10.4018/ijisscm.2015100102

Manzouri, M., Ab Rahman, M.N. \& Arshad, H., 2015, 'Issues in supply chain implementation: A comparative perspective', International Journal of Information Systems and Supply Chain Management (IIISSCM) 8(1), 85-101. https://doi. org/10.4018/ijisscm.2015010105

Morgan, R.M. \& Hunt, S.D., 1994, 'The commitment-trust theory of relationship marketing', The Journal of Marketing 58(3), 20-38. https://doi.org/10.1177/00222 4299405800302

Naude, M.J., Ambe, I.M. \& Kling, R., 2013, 'Supplier relationship managementanathema for the South African public procurement sector', Journal of Transport and Supply Chain Management 7(1), 1-8. https://doi.org/10.4102/jtscm.v7i1.93

Niehaus, G., Feiboth, H.W. \& Goedhals-Gerber, L.L., 2018, 'Investigating supply chain sustainability in South African organisations', Journal of Transport and Supply Chain Management 12(1), 1-11. https://doi.org/10.4102/jtscm.v12i0.335

Okdinawati, L., Simatupang, T.M. \& Sunitiyoso, Y., 2017, 'Multi-agent reinforcement learning for value co-creation of Collaborative Transportation Management (CTM)', International Journal of Information Systems and Supply Chain Management 3(10), 84-94. https://doi.org/10.4018/IJISSCM.2017070105

Özer, Ö. \& Zheng, Y., 2017, 'Establishing trust and trustworthiness for supply chain information sharing', in Ö. Özer \& Y. Zheng (eds.), Handbook of information exchange in supply chain management, pp. 287-312, Springer, Cham. https://doi. org/10.1007/978-3-319-32441-8_14

Oxford dictionary online, 2018, English Oxford Living dictionaries, viewed 07 September 2018, from https://en.oxforddictionaries.com/definition/trust.

Pallant, J., 2011, SPSS survival manual 4th edition: A step by step guide to data analysis using SPSS version 18, Open University Press, Maidenhead, Berkshire.

Ritter, T. \& Walter, A. 2012, 'More is not always better: The impact of relationship functions on customer-perceived relationship value', Industrial Marketing Management 41(1), 136-144. https://doi.org/10.1016/j.indmarman.2011.11.020

Saban, K.A. \& Luchs, R., 2011, 'The benefits of governing with a trust-centric strategy', Journal of Leadership, Accountability and Ethics 8(3), 43-55.

Saunders, M., Lewis, P. \& Thornhill, A., 2009, Research methods for business students, Pearson education, England, ISBN 1098764321.
Sharma, S.K. \& Bhat, A., 2014, 'Supply chain risks: Development of model and empirical evidence', International Journal of Applied Management Science 6(1) 45-64. https://doi.org/10.1504/IJAMS.2014.059293

Sharma, S.K., Bhat, A., Kumar, V. \& Agarwal, A., 2017, 'Path analysis model for supply chain risk management', International Journal of Information Systems and Supply Chain Management (IIISSCM) 10(2), 21-41. https://doi.org/10.4018/IJISSCM.201 7040102

Silva, M.E., Fritz, M.M. \& Nunes, B., 2017, 'Scanning insights on sustainability and supply chain management in Brazil', Journal of Operations and Supply Chain Management 10(1), 33-54. https://doi.org/10.12660/joscmv10n1p33-54

Slack, N., Brandon-Jones, A., Johnston, R., Singh, H. \& Phihlela, K., 2017, Operations management; Global and Southern African perspectives, 3rd edn., Pearson, Cape Town, ISBN: 9781775956600.

Steinle, C., Schiele, H. \& Ernst, T., 2014, 'Information asymmetries as antecedents of opportunism in buyer-supplier relationships: Testing principal-agent theory', Journal of Business-to-Business Marketing 21(2), 123-140. https://doi.org/10.108 $0 / 1051712 X .2014 .903457$

Sun, P.C., Pan, F.T., Wu, P.C. \& Kuo, C.C., 2014, 'An empirical study of B2B relationship value offering type as a moderator', Journal of Business Studies Quarterly 6(1), 79-97.

Swink, M., Melnyk, S.A., Cooper, M.B. \& Hartley, J.L., 2011, Managing operations across the supply chain, McGraw-Hill, New York.

Tolmay, A., 2012, 'Developing a relationship value model for the South African business to business automotive supply chain', Unpublished DBL thesis, University of South Africa, Pretoria.

Tolmay, A.S., 2017, 'The correlation between relationship value and business expansion in the South African automotive supply chains', Journal of Transport and Supply Chain Management 11, 1-8. https://doi.org/10.4102/ac.v17i1.450

Tolmay, A.S., 2018, 'An investigation into the personal interaction items which best explain the variation in trust within automotive supply chains', International Journal of Information and Supply Chain Management 11(2), 77-91. https://doi. org/10.4018/IJISSCM.2018040105

Tolmay, A.S. \& Venter, P., 2017, 'Relationship value antecedents in the South African automotive component supply chain', Acta Commercii 17(1), 1-8.

Ulaga, W. \& Eggert, A., 2006, 'Value-based differentiation in business relationships: Gaining and sustaining key supplier status', Journal of Marketing 70(1), 119-136. https://doi.org/10.1509/jmkg.70.1.119.qxd

Uslaner, E.M., 2013, 'Trust as an alternative to risk', Public Choice 157(3-4), 629-639. https://doi.org/10.1007/s11127-013-0082-x

Vieira, L.M., Paiva, E.L., Finger, A.B. \& Teixeira, R., 2013, 'Trust and supplier-buyer relationships: An empirical analysis', BAR, Rio de Janeiro 10(3/2), 263-280.

Vos, F.G.S., Pulles, N.J. \& Schiele, H., 2016, Commitment and power in the supply chain, paper delivered at the 25th Annual IPSERA Conference, Paper 65, Dortmund, 20th March.

Walter, A., Mueler, T.A. \& Helfert, G., 2000, 'The impact of satisfaction, trust, and relationship value on commitment: Theoretical considerations and empirical results' The 16th IMP Conference, Bath, United Kingdom, 7-9 September 2000, pp. 1-18.

Wisner, J.L., Tan, K-C. \& Leong, G.K., 2016, Principles of supply chain management: A balanced approach, Cengage Learning, Boston, MA.

Yaqub, M.Z. \& Hussain, D., 2013, 'How do the relational investments affect relational outcomes?', Journal of Applied Business Research (JABR) 29(2), 433-442. https:// doi.org/10.19030/jabr.v29i2.7648

Yeh, Y.P., 2016, 'Critical influence of relational governance on relationship value in strategic supply management', European Business Review 28(2), 137-154. https:// doi.org/10.1108/EBR-09-2014-0068 